Katarzyna Luzar-Błaż, Małgorzata Grodzińska-Jurczak, Joanna Cent

\title{
Partycypacja społeczna w zarządzaniu terenami chronionymi na przykładzie obszaru Natura 2000 - Dolinki Jurajskie
}

Streszczenie: Partycypacyjne zarządzanie obszarami chronionymi opierające się na współpracy różnych grup interesariuszy to najskuteczniejsza z dotychczas wypracowanych form gospodarowania zasobami przyrody. W Polsce tego typu model zarządzania jest wciąż podejściem nowym i pomimo sprzyjającej w tej materii legislacji nie jest stosowany rutynowo.

Celem niniejszej pracy było określenie potrzeb, preferencji, konfliktów oraz potencjału partycypacji różnych grup interesariuszy obszaru Natura 2000 - Dolinki Jurajskie PLH120005 do uczestnictwa w tworzeniu Planów Zadań Ochronnych (PZO) oraz w zarządzaniu niniejszym terenem. Analizowano również sieć połączeń pomiędzy instytucjami zarządzającymi, wizję Dolinek wśród interesariuszy oraz współpracę pomiędzy nimi. Badania miały charakter jakościowy i obejmowały technikę wywiadu pogłębionego, analizę SWOT i analizę powiązań SWOT; zostały przeprowadzone w czterech gminach położonych na terenie Dolinek Jurajskich w okresie od maja do lipca 2015 r. Wyniki badań mogą stanowić przydatny materiał dla instytucji zajmujących się zarządzaniem przyrodą zarówno na terenie badawczym, jak i na innych obszarach Natura 2000 w Polsce.

Słowa kluczowe: partycypacja publiczna, Natura 2000, plany zadań ochronnych, zarządzanie ochroną przyrody, społeczne aspekty ochrony przyrody.

\section{Wstęp. Partycypacja w ochronie przyrody}

Zagadnienie partycypacji odgrywa istotną rolę w ochronie przyrody. Liczne badania wskazują, że angażowanie różnych grup interesariuszy w działania ochronne

Mgr Katarzyna Luzar-Błaż, Instytut Nauk o Środowisku, Uniwersytet Jagielloński, ul. Gronostajowa 7, 30-387 Kraków, k.luzar@gmail.com; prof. dr hab. Małgorzata Grodzińska-Jurczak, Instytut Nauk o Środowisku, Uniwersytet Jagielloński, ul. Gronostajowa 7, 30-387 Kraków, m.grodzinska-jurczak@uj.edu.pl; dr Joanna Cent, Instytut Nauk o Środowisku, Uniwersytet Jagielloński, ul. Gronostajowa 7, 30-387 Kraków, joanna.cent@uj.edu.pl. 
danego obszaru może poprzez współpracę, tworzenie relacji, interakcje, szukanie kompromisów czy wreszcie podjęcie wspólnej odpowiedzialności prowadzić do ochrony znacznie efektywniejszej i dużo lepszej jakości manifestującej się ostatecznie polepszeniem stanu przyrody (Yosie, Herbst, 1998; Grodzińska-Jurczak, Cent 2011a; Ducker 2012; Bal i in. 2013; Calvet-Mir i in. 2015). Stopień usprawnienia systemu ochrony zależy jednak od powszechności partycypacji (liczba i różnorodność grup interesariuszy ostatecznie włączonych w prowadzone działania ochronne), jej zasięgu (różne poziomy administracyjne) i siły (stopień zaangażowania obywateli w procesy decyzyjne). Generalnie, im więcej osób reprezentujących różnorodne grupy osób zaangażowanych w prace na rzecz danego terenu chronionego (multipartner governance) (Lemos, Agrawal 2006; Brodie i in. 2009) mających szansę działać na różnych szczeblach organizacji społeczności (multilevel governance) (Lewenstein, Schindler, Skrzypiec 2010; Olech 2011), tym większa szansa na sprawniejszą jego ochronę.

Partycypacja w ochronie przyrody podobnie jak w innych sektorach gospodarki może mieć różną moc, określaną na skali poziomów (szczebli) zgodnie z koncepcją drabiny partycypacji (Arnstein 1969). Osiem szczebli drabiny przyporządkowuje się do trzech głównych kategorii: informowanie, konsultowanie, współdecydowanie (Długosz, Wygnański 2005). Najwyższy stopień uczestnictwa obywateli to współdecydowanie. Przyczynia się ono do wzrostu kapitału społecznego poprzez podjęcie odpowiedzialności za wydawane decyzje, które stają się obowiązujące. To z kolei prowadzi do wzrostu kompetencji społeczeństwa w zarządzaniu dobrami publicznymi, które z niczyich stają się "nasze" i odpowiednio zagospodarowywane (Poteete, Janssen, Ostrom 2010). Generalnie społeczności silnie partycypacyjne rozwijają się szybciej, problemy rozwiązują sprawniej, a cele osiągają łatwiej. Dodatkowo współpraca oparta na partycypacji wyzwala współodpowiedzialność nie tylko za decyzje, ale także za ich realizację oraz pozwala na efektywniejsze zarządzanie poprzez samostanowienie (Gawin, Gliński 2006; Ostrom 2010). Z drugiej strony, decyzje podjęte przez organy zarządcze lepiej odpowiadają preferencjom i potrzebom społeczności lokalnej, jeśli może ona uczestniczyć w procesie decyzyjnym. Zyskują na tym także władze, ponieważ tak podjęte decyzje są bardziej akceptowalne społecznie, a przez to mają większą skuteczność ich wdrożenia (Strzelecka, Grodzinska-Jurczak, Pietrzyk-Kaszynska 2013; Dubel 2016).

W Polsce, choć partycypacja w ochronie przyrody jest zagwarantowana legislacyjnie, taki model zarządzania przyrodą, $w$ tym terenami chronionymi, jest jeszcze rzadko realizowany w praktyce (Ustawa o udostępnianiu informacji o środowisku i jego ochronie, udziale społeczeństwa w ochronie środowiska oraz o ocenach oddziaływania na środowisko, 2008). Wynika to najczęściej z niskiej świadomości społeczeństwa odnośnie do możliwości włączania się w procesy decyzyjne oraz słabej wiary w sprawczość działania na rzecz ochrony przyrody (Cent i in. 2007). 


\section{Europejska Sieć Ekologiczna - Natura 2000}

Europejska Sieć Ekologiczna - Natura 2000 to najnowsza, spośród wszystkich obecnie obowiązujących, forma ochrony przyrody w Polsce skierowana na zachowanie, ochronę i poprawę jakości najcenniejszych siedlisk przyrodniczych w skali całej Europy. Działalność gospodarcza człowieka na terenie sieci Natura 2000 nie podlega ograniczeniom, jeżeli nie oddziałuje negatywnie na środowisko przyrodnicze danego obszaru (Ustawa o Ochronie Przyrody z dnia 16 kwietnia 2004 r.), co w porównaniu z innymi formami ochrony przyrody stanowi o jej unikatowości (Górska 2015).

W większości krajów członkowskich, w tym także w Polsce, obszary naturowe zostały wyznaczane praktycznie wyłącznie na podstawie przyrodniczych kryteriów naukowych, bez uwzględnienia czynnika społecznego czy ekonomicznego, jak też często bez wystarczającego poinformowania bezpośrednio zainteresowanych o założeniach Natury 2000. Takie podejście prowadziło najczęściej do niezrozumienia potrzeby wprowadzenia nowej formy ochrony, nieporozumień, a w ostateczności do nieprzychylności społeczności, władz lokalnych i przedstawicieli sektora biznesu wobec nowo tworzonej sieci (Alphandéry, Fortier 2001; Hockings i in. 2006; Grodzińska-Jurczak 2008; Czarnecki 2010; Habuda 2010; Perepeczko 2010; Grodzińska-Jurczak, Cent 2011b).

Dla każdego wyznaczonego obszaru istnieje obowiązek stworzenia tzw. Planu Zadań Ochronnych (PZO) lub Planu Ochrony (PO), dokumentu planistycznego stanowiącego narzędzie do zarządzania obszarem Natura 2000. Stąd zasadność zapisów regulująca obowiązek włączania w prace nad jego tworzeniem jak najszerszej grupy interesariuszy. W większości państw UE zainteresowanie lokalnych społeczności włączaniem się w tworzenie PZO jest niewielkie, a czasem wywołuje wręcz opór, skutkując ostatecznie różnego rodzaju konfliktami. Przyczynami ich najczęściej są: brak rzetelnych informacji o sieci, brak zrozumienia tego typu formy ochrony przyrody, aspekt własności gruntów objętych siecią czy brak kultury angażowania się w działania zewnętrzne (Julien i in. 2000; Guzal-Dec, Zwolińska-Ligaj 2010; Hirschnitz-Garbers, Stoll-Kleemann 2011; Grodzińska-Jurczak i in. 2012; Kamal, Grodzińska-Jurczak 2014). Obowiązek konsultacji i partycypacji społeczeństwa przy tworzeniu PZO jest zagwarantowany prawnie, a jego procedura polega na możliwości składania uwag i wniosków do ogłoszonego projektu planu w momencie jego przygotowywania. Proces tworzenia planu obejmuje również identyfikację wszystkich interesariuszy z terenu PZO oraz konsultacje z nimi (Rejt 2013). Jak pokazuje praktyka, proces ten jednak nie zawsze jest skuteczny, głównie ze względu na sprzeczność interesów poszczególnych grup interesariuszy, konflikt wartości, brak lub niedostateczne informowanie na temat możliwości uczestnictwa 
w tworzeniu PZO (Dubel i in. 2013). Tam jednak, gdzie PZO uchwalano z dużą reprezentacją lokalnych społeczności, przyjmował on zdecydowanie lepszy kształt, a ostateczna efektywność zarządzania terenem była wyższa (Cent, GrodzińskaJurczak, Pietrzyk-Kaszyńska 2014).

Celem niniejszej pracy była diagnoza potrzeb, preferencji, konfliktów oraz potencjału partycypacji różnych grup interesariuszy obszaru Natura 2000 - Dolinki Jurajskie PLH120005 w zakresie uczestnictwa lokalnej społeczności w tworzeniu PZO oraz w zarządzaniu tym terenem. Analizowano również sieć połączeń pomiędzy instytucjami zarządzającymi, wizję Dolinek wśród różnych grup interesariuszy, a także ich współpracę.

\section{Teren i metodyka badań}

Badania prowadzono w czterech gminach: Wielka Wieś, Zabierzów, Jerzmanowice-Przeginia i Krzeszowice położonych na terenie obszaru Natura 2000 PLH120005 Dolinki Jurajskie. Dolinki to specjalny obszar ochrony siedlisk o dużej różnorodności biologicznej, którego przedmiotem ochrony jest 10 typów siedlisk wymienionych w załączniku I Dyrektywy Siedliskowej oraz pięć gatunków z załącznika II. Obejmuje on fragmenty Parku Krajobrazowego o łącznej powierzchni 886,5 ha oraz pięć rezerwatów przyrody (Zawartka 2013). Plan Zadań Ochronnych dla Dolinek jest obecnie w trakcie opracowywania. Towarzyszą temu działania informacyjno-konsultacyjne podejmowane przez Regionalną Dyrekcję Ochrony Środowiska w Krakowie i organizacje pozarządowe w ramach działań projektowych. Warto tu wymienić projekt „Misja Natura” (http://www.misjanatura.fwie.pl/index. $\mathrm{php} / \mathrm{pl} /$ ) zrealizowany przez Fundację Wspierania Inicjatyw Ekologicznych czy „Wspólne Zarządzanie Przyrodą - partycypacyjne mapowanie trenów chronionych” (https://crs.org.pl/projekty/wspolne-zarzadzanie-przyroda/) przeprowadzone przez Stowarzyszenia Centrum Rozwiązań Systemowych (szczegóły w części „Dyskusja”). Oba dotyczyły usprawnienia uczestnictwa lokalnych społeczności w zarządzaniu obszarem Natura 2000 - Dolinki Jurajskie.

Ze względu na bogactwo przyrodnicze i krajobrazowe Dolinki Jurajskie to teren bardzo atrakcyjny turystycznie. Gminy tego obszaru w swoich strategiach rozwoju (SRG) stawiają właśnie na walor przyrodniczy terenów Natury 2000, Parku Krajobrazowego i stanowi to główny bodziec ich rozwoju (SRG JerzmanowicePrzeginia, 2014; SRG Wielka Wieś, 2014; SRG Zabierzów, 2014; SRG Krzeszowice, 2015). Analizując potencjał społeczny gmin, warto wspomnieć o wyższej liczbie organizacji pozarządowych niż przeciętna w Polsce, co może świadczyć o zwiększonej aktywności społeczności lokalnych. Struktura wykształcenia ludności wiejskiej i miejskiej w powiecie krakowskim jest zbliżona, co może stanowić potencjał 
rozwoju tego regionu. Kultura i tradycje ludowe analizowanych gmin są bogate, a liczba klubów i kół sportowych jest większa niż średnio w całym województwie małopolskim (Dubel i in. 2016).

Teren badawczy został wybrany nieprzypadkowo. Kierowano się przy tym interesującymi dla badaczy zmiennymi przyrodniczymi, społecznymi i administracyjnymi, takimi jak bogactwo przyrodnicze, potencjał społeczny gmin, wciąż nieopracowany $\mathrm{PZO}$, już prowadzone działania informacyjno-edukacyjne na tamtejszym terenie, jak też współpraca autorów z organizacjami je realizującymi.

Dobór respondentów miał charakter celowy. Kryteria wyboru stanowiły: reprezentatywność rozmówców gmin, wiedza o Dolinkach oraz uzyskanie różnych perspektyw postrzegania zarządzania przyrodą tego obszaru. Respondentami byli przedstawiciele sektora publicznego, pozarządowego i prywatnego, znajdowali się wśród nich pracownicy urzędów gmin czterech miejscowości włączonych w badania, NGOs (Stowarzyszenie Ratuj Tenczyn, Polski Związek Alpinizmu, Studenckie Koło Przewodników Górskich w Krakowie, Stowarzyszenie Ostaniec), eksperci przyrodniczy (Regionalna Dyrekcja Ochrony Środowiska - RDOŚ, Tatrzański Park Narodowy - TPN, Małopolski Instytut Kultury - MIK, Zespół Parków Krajobrazowych Województwa Małopolskiego - ZPKWM) oraz lokalni przedsiębiorcy. Dobierano ich na podstawie informacji uzyskanych w trakcie analizy danych zastanych z urzędów gmin, internetu, wcześniejszych projektów realizowanych na terenie Dolinek itp. Kolejni respondenci pomagali w docieraniu do następnych, zgodnie z metodą kuli śnieżnej. W miarę jak informacje w wywiadach zaczynały się powtarzać, uznano, że nasycenie zebranych danych jest wystarczające do analizy (Elsawah i in. 2015).

W badaniach posłużono się techniką pogłębionego, częściowo ustrukturalizowanego wywiadu. Pytania podczas wywiadu były zadawane według przewodnika wywiadu dotyczącego: cech Dolinek (wartości, aktywności, preferencje planowania); problemów Dolinek (konflikty, trudności), partycypacyjnego zarządzania Dolinkami i wizji rozwoju tego terenu. Po wcześniejszej zgodzie respondenta wywiad był nagrywany, a następnie poddawany transkrypcji. W sumie w okresie od maja do lipca 2015 r. przeprowadzono 16 wywiadów. Ich czas trwania wynosił od 52 minut do 2 godzin 50 minut.

Dane uzyskane w wywiadach kodowano i porównywano przy użyciu programu QDA miner. Na podstawie przewodnika wywiadu oraz pytań badawczych zostały a priori wyróżnione kody odpowiadające zagadnieniom poruszanym przez respondentów, które przypisywano większym fragmentom - co najmniej jedno zdanie wypowiedzi. Wyróżniono cztery kody główne: „Kto zarządza”, „Problemy Dolinek”, „Zagospodarowanie Dolinek”, „Zarządzanie Dolinkami”, którym przypisywano podkategorie - podkody. $\mathrm{W}$ toku analizy dokonano zmian, przemodelowano oraz 
uzupełniono kody ze względu na otrzymane wyniki. Następnie, po przypisaniu do treści odpowiedzi na poszczególne pytania odpowiednich kodów, przeprowadzono analizę otrzymanych wyników w poszczególnych grupach respondentów poprzez zliczenie liczby i częstości pojawiania się kodów (Silverman 2010).

Zastosowano także analizę SWOT oraz analizę powiązań SWOT w celu porównania różnych grup respondentów między sobą i poznania najlepszego potencjalnego kierunku rozwoju zarządzania Dolinkami. Narzędzie SWOT polega na przeanalizowaniu i uporządkowaniu zagadnienia pod kątem czterech kategorii: jego mocnych stron (strengths), słabych stron (weaknesses), szans (opportunities) i zagrożeń (threats). Dzięki takiemu opisaniu i identyfikacji oddziaływań różnych czynników rozwoju możliwe jest bardziej skuteczne zarządzanie danym zagadnieniem, wypracowanie lepszych strategii działania poprzez koncentrację na zdiagnozowanych obszarach najbardziej problemowych. Zastosowano także analizę powiązań SWOT, która polega na odpowiedzi na pytanie o wzajemne interakcje zidentyfikowanych czynników: Czy określona mocna/słaba strona pozwala ograniczyć/wykorzystać daną szansę, zmniejsza/potęguje dane zagrożenie? W zależności od liczby interakcji między danymi czynnikami można wdrożyć konkretną strategię działania, najskuteczniejszą w danej sytuacji. Wybór następuje poprzez zliczenie interakcji oraz dopasowanie takiej strategii, przy której występuje ich najwięcej (Żabiński 2000).

\section{Wyniki}

Wyniki analizy SWOT pozwoliły wyłonić najważniejsze mocne i słabe strony, szanse i zagrożenia, które, zdaniem respondentów, wywierają istotny wpływ na zarządzanie tym obszarem. Analizie poddano przedstawicieli instytucji publicznych, ekspertów, organizacji pozarządowych i przedsiębiorców.

I tak, wśród instytucji publicznych mocne strony stanowi duża moc decyzyjna, siła przebicia oraz dobra znajomość środowiska społecznego, dzięki czemu istnieje szansa, by ta grupa interesariuszy pozyskiwała środki finansowe na cele środowiskowe, ponieważ walory przyrodnicze są ważne w promocji gmin. Słabymi stronami instytucji publicznych są: niewielka chęć współpracy z innymi instytucjami, postrzeganie ochrony przyrody jako ograniczenia dla rozwoju danego terenu oraz nie zawsze faktyczne stosowanie proponowanych rozwiązań w praktyce. Przez to zagrożenie może stanowić brak realnego działania w celu poprawy i utrzymania właściwego stanu przyrody oraz brak uwzględniania innych pespektyw przy podejmowaniu decyzji, które mogą być zbyt jednostronne.

W grupie ekspertów lokalnych do mocnych stron można zaliczyć: dużą wiedzę przyrodniczą o obszarze Dolinek, pasję do swojej dziedziny, znajomość 
uwarunkowań środowiskowych i społecznych dla badanego terenu, co stawia ich w roli autorytetu merytorycznego wśród innych grup. Słabymi stronami ekspertów lokalnych są: brak siły decyzyjnej i zaplecza finansowego na realizację ewentualnych działań oraz używany przez nich specjalistyczny, trudny dla przeciętnego odbiorcy język. Choć wiedza ekspertów jest rzetelna i oparta na danych czerpanych z monitoringu przyrodniczego, a formułowane przez nich opinie o zarządzaniu Dolinkami mają podstawy w danych naukowych, brakuje im dobrej komunikacji i przepływu informacji pomiędzy poszczególnymi instytucjami. Przez to mogą wzbudzać nieufność innych, szczególnie w przypadku, gdy poszczególne instytucje zgromadzą odmienne dane.

Wśród NGOs Dolinek mocnymi stronami są: otwartość na innych interesariuszy i motywacja do działania wynikająca z potrzeby realizowania swoich przekonań i pasji. Szansami NGO są: umiejętność wpływania na decyzje innych interesariuszy oraz duża chęć do współpracy i włączenia się w zarząadzanie. Natomiast wśród słabych stron tej grupy należy wymienić: niską rzeczywistą aktywność tego sektora mimo dużej liczby organizacji. Sektor non-profit jest zależny od zewnętrznego finansowania, dlatego zagrożeniem dla NGO jest chęć włączania się tej grupy, gdy istnieje wymierna korzyść, np. pozyskanie funduszy na działanie dla danej jednostki, jak też koncentracja na jednym aspekcie w partycypacji, którym interesuje się dana NGO, z pominięciem innych, czasami równie ważnych.

Ostatnią analizowaną grupą interesariuszy byli przedsiębiorcy, których mocnymi stronami są: umiejętność promocji terenu Dolinek i jego walorów przyrodniczych oraz chęć ochrony przyrody, ponieważ stanowi ona podstawę do osiągania zysków z turystyki dla tej grupy. Dzięki temu potencjałem przedsiębiorców są: rozwijanie sektora i oferty turystycznej Dolinek oraz pozyskiwanie funduszy inwestorów na projekty środowiskowe. Słabe strony przedsiębiorców to mała przejrzystość ich działania, brak współpracy oraz chęci uczestnictwa w zarządzaniu Dolinkami, dystans między sektorem prywatnym a innymi interesariuszami Dolinek. Wszystkie ze słabych stron w pewien sposób izolują przedsiębiorców od reszty grup interesariuszy.

W celu pogłębienia i rozszerzenia analizy SWOT przeprowadzono także analizę powiązań SWOT. Kryteriami tej analizy były wzajemne interakcje pomiędzy mocnymi i słabymi stronami, szansami, zagrożeniami u różnych podmiotów uczestniczących w zarządzaniu, aby określić priorytetowe potrzeby w partycypacji oraz podejmowaniu współpracy pomiędzy poszczególnymi interesariuszami. Do analizy, zgodnie z metodyką jej przeprowadzania, włączono tylko po jednej, zdaniem respondentów, najbardziej znaczącej, mocnej oraz słabej stronie danego interesariusza Dolinek (tabela 1). Na podstawie przeprowadzonej analizy wydaje się, że najlepszą strategią w zarządzaniu Dolinkami jest strategia agresywna, ponieważ 
najwięcej interakcji (26) występuje w lewej górnej komórce macierzy - mocne strony/szanse (tabela 2).

Tabela 1. Zestawienie mocnych i słabych stron interesariuszy analizy powiązań SWOT Table 1. Strengths and weaknesses of stakeholders in SWOT analysis

\begin{tabular}{|c|c|c|}
\hline Interesariusz & Mocna strona & Słaba strona \\
\hline Instytucje publiczne & $\begin{array}{l}\text { duża moc decyzyjna, np. na co } \\
\text { przeznaczyć kapitał }\end{array}$ & $\begin{array}{l}\text { chęć współpracy z innymi } \\
\text { instytucjami raczej niewielka }\end{array}$ \\
\hline Eksperci lokalni & $\begin{array}{l}\text { znajomość uwarunkowań nie } \\
\text { tylko środowiskowych, ale także } \\
\text { społecznych, gospodarczych }\end{array}$ & brak zaplecza finansowego \\
\hline $\begin{array}{l}\text { Eksperci ochrona } \\
\text { środowiska }\end{array}$ & $\begin{array}{l}\text { formułowanie opinii o zarządzaniu } \\
\text { Dolinkami na podstawie danych } \\
\text { naukowych }\end{array}$ & trudny, specjalistyczny język \\
\hline NGO & poparcie i zaufanie społeczne & $\begin{array}{l}\text { NGO nie zawsze są stroną działającą } \\
\text { autonomicznie }\end{array}$ \\
\hline Przedsiębiorcy & $\begin{array}{l}\text { ochrona przyrody Dolinek jako } \\
\text { podstawa do osiągania zysków } \\
\text { z turystyki }\end{array}$ & $\begin{array}{l}\text { nieufność wobec interesariuszy, } \\
\text { niechęć do informowania o swoich } \\
\text { działaniach }\end{array}$ \\
\hline
\end{tabular}

Źródło: opracowanie własne.

Source: own study.

Tabela 2. Podsumowanie wyników analizy powiązań SWOT - macierz interakcji Table 2. Summary of SWOT analysis - matrix of interaction

\begin{tabular}{lcc}
\hline Liczba interakcji & Szanse & Zagrożenia \\
\hline Mocne strony & 26 & 19 \\
Słabe strony & 16 & 17 \\
\hline
\end{tabular}

Źródło: opracowanie własne.

Source: own study.

Wywiady pogłębione częściowo ustrukturalizowane dotyczyły wielu aspektów Dolinek, takich jak: walory i korzyści z nich czerpane, aktywności podejmowane przez ich interesariuszy, konflikty pojawiające się pomiędzy aktywnościami a ochroną przyrody, główne problemy tego obszaru, możliwości partycypacji i współpracy $\mathrm{w}$ zarządzaniu, potrzeby w partycypacyjnym zarządzaniu oraz preferencje interesariuszy dotyczące zagospodarowania Dolinek w przyszłości.

W wywiadach wszyscy respondenci podkreślali wiele szczególnych, ich zdaniem, walorów badanego terenu, szczególnie tych o charakterze niekomercyjnym. 
Jednymi z najczęściej wymienianych walorów były: bliskie położenie Krakowa, rozbudowana infrastruktura, przestrzeń zarówno do rekreacji, jak i do obcowania z dziką, dobrze zachowaną przyrodą. Oprócz tego głównie eksperci lokalni i specjaliści z zakresu ochrony środowiska wskazywali także na duże wartości poznawcze i naukowe okolicy, wykazując się przy tym dużą wiedzą o Dolinkach. Wiedza ta dotyczyła gatunków chronionych, budowy geologicznej tego regionu i form ochrony przyrody. Jeśli chodzi o komercyjne znaczenie Dolinek, to respondenci wymieniali najczęściej: turystykę kwalifikowaną - głównie wspinaczkę, produkt lokalny oraz agroturystykę. Instytucje publiczne uwzględniały także jako ważne aspekty: przemysł oraz udział sektora prywatnego w rozwoju Dolinek. Zdaniem osób udzielających wywiadów atrakcyjność przyrodnicza oraz liczne walory zarówno krajobrazowe, jak również związane z lokalizacją i infrastrukturą, sprawiają, że w Dolinkach podejmowanych jest wiele aktywności. Podejmują je zarówno mieszkańcy, szczególnie ci, którzy sprowadzili się na ten obszar ze względu na niniejsze walory, jak i turyści, którzy odwiedzają to miejsce, według respondentów najczęściej w formie turystyki weekendowej. Główne aktywności dostępne dla osób odwiedzających Dolinki to: turystyka weekendowa, poznawanie i doświadczanie przyrody, spacery, speleologia, pielgrzymki, grill. Jeśli chodzi o sport, to najczęściej interesariusze wymieniali: jogging, nordic walking, quad, rower, wspinaczkę, rzadziej pojawiały się: golf, jazda konna, kulig, narty biegowe. Jak zgodnie stwierdzają respondenci, walory przyrodnicze stanowią podstawę zarówno dla korzyści finansowych, jak i niefinansowych, dla jakości spędzania czasu, a zieleń, bliskość przyrody sprzyja wypoczynkowi i rekreacji. Bogactwo przyrodnicze jest także źródłem surowca dla rozwoju przemysłu i rzemiosła na tym obszarze. Zdaniem respondentów, konflikty związane $\mathrm{z}$ wykluczającymi się aktywnościami dotyczą najczęściej obszaru ochrony przyrody. Często zdarza się, że turyści w rezerwatach przyrody łamią przepisy, np. poprzez zbaczanie ze szlaków, wspinaczkę w niedozwolonych do tego miejscach. Według respondentów konflikty pomiędzy aktywnościami związane są także bardzo mocno z grupą osób jeżdżących na quadach, niszczących przyrodę i stanowiących uciążliwość dla innych interesariuszy, a także z grupą wpinaczy, którzy stanowią dla mieszkańców zagrożenie dla ich prywatnej przestrzeni, np. przez zastawianie posesji autami, korzystanie ze skałek tuż przy ich domach.

W przeprowadzanych wywiadach najczęściej (20) pojawiającym się problemem Dolinek jest presja urbanistyczna. Zdaniem interesariuszy istnieje trudność, aby pogodzić kwestie ochrony środowiska z rozwojem inwestycyjnym oraz zabudowy mieszkalnej, ponieważ atrakcyjność Dolinek i ich bliskość od Krakowa sprawiają, że dużo ludzi chce się osiedlać na tym terenie i coraz więcej turystów odwiedza to miejsce. Innym, pojawiającym się często (11) w wypowiedziach respondentów 
problemem jest dostęp do Dolinek. Zdaniem ekspertów lokalnych jest to związane z różnicami między mieszkańcami rdzennymi a mieszkańcami przyjezdnymi, którzy osiedlając się na tym atrakcyjnym terenie, wykupując swoją działkę, uważają ją za swoją wyłączną własność.

Przeprowadzone wywiady pokazały, że respondenci mają wiedzę na temat obowiązku przeprowadzania konsultacji społecznych i włączania lokalnych społeczności w zarządzanie przyrodą tego terenu, jednak w praktyce nie zawsze udaje im się to realizować. Opinie respondentów odnośnie do możliwości współpracy różnych interesariuszy i instytucji w gospodarowaniu Dolinkami są bardzo podzielone. Najbardziej chętnymi grupami do współpracy są eksperci lokalni, NGO oraz lokalne grupy działania (9). Natomiast głównymi problemami we współpracy są: rozdrobnienie decyzji, brak przepływu informacji pomiędzy interesariuszami oraz trudność w dotarciu do wszystkich beneficjentów tego terenu, a także brak jednego koordynatora Dolinek. W partycypacyjnym zarządzaniu największymi potrzebami są (16): określenie wspólnej wizji Dolinek oraz zaangażowanie lokalnych społeczności. Jednak mieszkańcom coraz bardziej zależy na jakości wody, powietrza, stanie fauny i flory w Dolinkach. Teoretycznie istnieje więc warty wykorzystania potencjał poprzez włączanie mieszkańców w zarządzanie tym obszarem. Grupy interesariuszy, które powinny być włączane w zarządzanie, to: mieszkańcy, samorządy lokalne, służby ochrony przyrody, środowisko naukowe, organizacje pozarządowe, kluby sportowe, przedstawiciele grup wykonujących popularne aktywności.

$\mathrm{W}$ przeprowadzonych $\mathrm{z}$ różnymi grupami interesariuszy wywiadach $\mathrm{w}$ aspekcie przyszłego zagospodarowania Dolinek najczęściej i wielokrotnie (19) pojawiającym się wątkiem była turystyka. Mówiono o potrzebie popularyzacji Dolinek, o braku zintegrowania informacji, niedostatecznej promocji tego regionu. Wielokrotnie (15) mówiono o konieczności uporządkowania i wyznaczenia miejsc do poszczególnych aktywności w Dolinkach, co pomogłoby w łagodzeniu konfliktów. Zdaniem osób udzielających wywiady, istnieje potrzeba wypracowania takiego systemu zarządzania obszarem, aby w jak najmniejszym stopniu ingerować w przyrodę. Interesariusze uważają także za niezbędne jasne sprecyzowanie oferty regionu dla potencjalnego turysty o różnym profilu i zainteresowaniach z możliwościami aktywności, rekreacji, edukacji przyrodniczej, a także z bazą noclegową i gastronomiczną, parkingami.

\section{Dyskusja}

Wątek poczucia odpowiedzialności mieszkańców za okoliczną przyrodę oraz często wolontaryjne przystępowanie do zarządzania nią pojawia się najczęściej w krajach, gdzie partycypacja, nie tylko w sektorze środowiska naturalnego, ma 
długą historię. Najlepsze praktyki, przeważnie zakończone wzrostem efektywności gospodarowania zasobami przyrodniczymi, pochodzą z USA, Kanady i niektórych krajów EU-15. Wszystkie z tych państw mają polityki priorytetowo zakładające zarządzanie przyrodą bazujące na aktywnej, szerokiej partycypacji (environmental multipartner governance) praktycznie na wszystkich poziomach administracyjnych (environmental level governance) (Strzelecka, Grodzinska-Jurczak, PietrzykKaszynska 2013; Calvet-Mir i in. 2015). Partycypacyjne zarządzanie obszarami chronionymi w Polsce, choć ukonstytuowane legislacyjnie, wciąż traktowane jest przez tak naukowe, jak i decydenckie środowiska $z$ dużą rezerwą i panuje przekonanie o małej jego skuteczności. Większość zapisów prawnych została sformułowana zbyt ogólnie, co skutkuje brakiem bezpośredniej konieczności jego wykonawstwa przez różne grupy decydentów, jak też jego ewentualnej egzekucji przez instytucje zarządzające ochroną przyrody (Paloniemi i in. 2015; Pietrzyk-Kaszyńska, Grodzińska-Jurczak 2015).

Na terenie Dolinek Jurajskich prowadzono już wcześniej badania dotyczące aspektu społecznego w ochronie środowiska i przyrody. Jedne z nich to działania w zakresie projektu „Szlakiem Dolinek Podkrakowskich” mające na celu zintegrowanie informacji o Dolinkach, np. turystycznych czy przyrodniczych, i koordynacja zarządzania przyrodą tego terenu, podobnie jak w niniejszej pracy, przy użyciu analizy SWOT różnych grup turystów odwiedzających Dolinki oraz analiza SWOT grup, które mogłyby potencjalnie zostać przyrodniczym koordynatorem tego terenu (http://docslide.pl/documents/szlaki-dolinki-podkrakowskie.html). Kolejne to projekt „Misja Natura” (LIFE+), w ramach którego były prowadzone konsultacje społeczne, akcje informacyjne o Naturze 2000 oraz szkolenia z udziałem różnych grup interesariuszy. W rezultacie powstał model konsultacji dla tego terenu z podsumowaniem wszystkich kluczowych problemów oraz poruszanych zagadnień (http://www.misjanatura.fwie.pl/index.php/pl/).

Projekt „Wspólne zarządzanie przyrodą", którego częścią była niniejsza praca, obejmował oprócz opisanych tu wywiadów i analizy SWOT spotkania w lokalnych szkołach i warsztaty z użyciem mapowania partycypacyjnego. Dzięki temu rozszerzono dotychczasowe informacje o tym terenie, jak też z sukcesem włączono przedstawicieli lokalnej społeczności w zarządzanie przyrodą (Dubel i in. 2016). I tak, analiza SWOT oraz analiza powiązań SWOT pozwoliła na wyłonienie kluczowych problemów, z którymi warto się uporać w celu osiągnięcia efektywniejszego partycypacyjnego zarządzania Dolinkami. Najważniejsze z nich to: niewielka chęć współpracy instytucji publicznych z innymi interesariuszami, u ekspertów lokalnych brak zaplecza finansowego do działania, hermetyczność języka ekspertów ochrony środowiska, nieufność do innych interesariuszy oraz niechęć do informowania o swoich działaniach w grupie przedsiębiorców. Wyłonione zagadnienia powinny 
zostać wzięte pod uwage przy tworzeniu PZO, w Strategiach Rozwoju Gmin oraz wszystkich dokumentach istotnych z punku widzenia zagospodarowania obszaru Natura 2000 Dolinki Jurajskie. Najlepszą strategią w zarządzaniu Dolinkami, zgodnie z przeprowadzoną analizą SWOT, wydaje się strategia agresywna, promująca spożytkowanie atutów w sprzyjających warunkach zewnętrznych, w której podstawą jest ekspansja i zdywersyfikowany rozwój (Obłój 2007). Niniejszy obszar ma przewagę mocnych stron, które mogą pomóc wykorzystać szanse, jakimi są: walory przyrodnicze, możliwość pozyskania finansów na cele środowiskowe, rozwinięcie sektora turystycznego, współpraca z ekspertami lokalnymi i wykorzystywanie ich wiedzy oraz danych naukowych. Uzyskane wyniki analizy podkreślają też duży potencjał wykorzystania atutów tego obszaru w celu skuteczniejszego zarządzania przyrodą z udziałem jak największej liczby interesariuszy.

Zastosowanie w badaniach analizy SWOT oraz powiązań SWOT okazało się wartościową i adekwatną do niniejszej problematyki metodą. Choć wywodzi się ona z ekonomii oraz zarządzania i jest najczęściej wykorzystywana np. przy wdrażaniu nowych rozwiązań (Scolozzi i in. 2014), wartość jej zastosowania w ochronie środowiska i przyrody jest wysoka. Wynika nie tylko z faktu opisu czynników, które mogą znacząco wpływać na powodzenie lub niepowodzenie danej inwestycji, ale także z możliwości budowania na podstawie wyników tej analizy konkretnej strategii działania, aby osiągnąć długoterminowe, założone cele (Houben, Lenie, Vanhoof 1999). W przypadku Dolinek analiza SWOT umożliwiła diagnozę i ocenę najlepszego kierunku i strategii partycypacyjnego zarządzania tym obszarem. Nie byłoby to możliwe przy użyciu jedynie tradycyjnych metod ilościowych.

Rezultaty niniejszej pracy są zbliżone do wyników analizy SWOT dla rozwoju społeczno-gospodarczego Dolinek jako obszaru Natura 2000 (Dubel i in. 2016), w których wyróżniono podobne czynniki: mocne strony - wysokie walory krajobrazowe i przyrodnicze, duży potencjał rozwoju turystyki, szanse - możliwości pozyskiwania funduszy europejskich, słabe strony: niska integracja mieszkańców. Natomiast w tej analizie zwrócono uwagę na wątki, które nie były mocno akcentowane w przeprowadzonych wywiadach, czyli na warunki sprzyjające rolnictwu i jego rozdrobnienie, konkurencja sąsiednich gmin, korzystna struktura wieku mieszkańców, ukryte bezrobocie agrarne, dominacja tradycyjnych branż gospodarki. Wydaje się, że także te elementy powinny być brane pod uwagę przy tworzeniu PZO. Pozostałe wątki $\mathrm{z}$ analizy pojawiły się również $\mathrm{w}$ wywiadach, są to m.in.: atrakcyjność obszaru jako miejsca zamieszkania, lokalne dziedzictwo kulturowe, wysoki udział przyjezdnych wśród mieszkańców, którzy nie identyfikują się z lokalną społecznością, niedostatecznie rozwinięta baza infrastrukturalna turystyki, zwiększająca się popularność turystyki weekendowej, krajoznawczej i agroturystyki. 
Analiza SWOT przeprowadzona w ramach projektu „Szlakiem Dolinek Podkrakowskich" wyłoniła trzech potencjalnych koordynatorów Dolinek, którzy mogliby promować ten teren i kontaktować pomiędzy sobą interesariuszy. Znalazły się wśród nich analizowane w niniejszej pracy: organizacja pozarządowa, instytucja publiczna i firma komercyjna. Jeśli chodzi o sektor pozarządowy, to podkreślane były jego: kreatywność, elastyczność pracy, misja społeczna, kontakty z innymi. Walorami wyboru na koordynatora instytucji publicznej są: lokalne zakorzenienie, zaplecze, jeśli chodzi o miejsce i media. Natomiast trzeci podmiot, który został wyłoniony jako potencjalny koordynator Dolinek, to przedsiębiorstwo, ze względu na dysponowanie odpowiednimi środkami finansowymi i planami rozwoju Dolinek w stosunkowo szybkim tempie. Jak widać, także na podstawie przeprowadzonych wywiadów, do tej pory ta kwestia nie została rozwiązana i dalej brakuje dobrej instytucji koordynującej zarządzanie przyrodą w Dolinkach, o czym bardzo często mówili respondenci.

Wywiady pokazały, że interesariusze Dolinek znają wiele walorów tego miejsca oraz wiedzą, że bogactwo i piękno przyrody stanowi podstawę dla rozwoju tego obszaru. Bardzo istotnym aspektem pojawiającym się zarówno w kontekście znaczenia Dolinek, jak i zarządzania oraz planów ich zagospodarowania był wątek dotyczący turystyki, najczęściej kodowany w transkrypcjach wywiadów. Jest to szansa do promowania gospodarowania według zasad zrównoważonego rozwoju, ponieważ naturalną bazę dla rozwoju turystyki stanowią walory przyrodnicze i krajobrazowe. Istnieje wiele programów, w ramach których można starać się o dofinansowanie agroturystyki, np. Program Rozwoju Obszarów Wiejskich na lata 2014-2020 (PROW 2014-2020, http://www.minrol.gov.pl/Wsparcie-rolnictwa/ Program-Rozwoju-ObszarowWiejskich-2014-2020). Warto więc informować interesariuszy Dolinek o takich możliwościach, aby mogli wykorzystywać potencjał, jaki tkwi w turystyce na tym terenie.

Respondenci wskazywali wiele walorów Dolinek Jurajskich. Wydaje się, że może przyczyniać się to do chęci włączenia się interesariuszy w zarządzanie tym terenem, skoro jest on nadal dla nich ważny, przynosząc wiele różnorodnych korzyści. Respondenci wymieniali także liczne aktywności, które można podejmować na terenie Dolinek. Najczęściej pojawiającym się wątkiem była wspinaczka. Jest to zbieżne z modelem konsultacji dla Dolinek w projekcie „Misja Natura”, gdzie także była podkreślona duża rola tej aktywności w stosunku do innych. Z jednej strony wspinacze mogą negatywnie oddziaływać na przyrodę Dolinek, ale, jak podkreśla raport $\mathrm{z}$ „Misja Natura”, mogą także poprzez współpracę $\mathrm{z}$ instytucjami ochrony przyrody stworzyć nowe, lepsze rozwiązania ochronne i dbać o ten teren, a w rezultacie sprawować nad nim pieczę, tak jak, zdaniem ekspertów z tej dziedziny uczestniczących w projekcie, odbywa się to np. w USA, Niemczech czy Kanadzie 
(Camp, Knight 1998; Krajick 1999). Potwierdzają to także opinie interesariuszy zebrane $\mathrm{w}$ wywiadach do niniejszej pracy. Popularność wspinaczki przejawia się np. w opracowywaniu przewodników z trasami i instrukcjami odnośnie do konkretnych skałek, np. „Korona północnego Krakowa przewodnik wspinaczkowy”, wydany przez Fundację Wspierania Rozwoju Wspinaczki Wspinka w 2015 r. Tak samo autorzy raportu „Misja Natura” zwracają uwagę na problem, który bardzo często pojawiał się także w wywiadach, dotyczący presji inwestycyjnej w Dolinkach. Wiąże się on $\mathrm{z}$ wyprzedawaniem gruntów rolnych pod zabudowę mieszkalną, co jest niekorzystne ze względów społecznych, środowiskowych oraz estetyki krajobrazu. Ze względu na bliskość Krakowa oraz Aglomeracji Śląskiej teren Dolinek jest bardzo atrakcyjnym miejscem dla inwestorów budowlanych, przez co może utracić swoją atrakcyjność turystyczno-rekreacyjną, która obecnie stanowi jedno z ważniejszych źródeł utrzymania się lokalnej społeczności (http://www.misjanatura.fwie.pl/images/pdf/Raport\%20\%20z\%20przeprowadz_szkol_D1.pd).

Kolejnym ważnym wątkiem pojawiającym się w wywiadach jest potrzeba współpracy pomiędzy różnymi grupami interesariuszy w Dolinkach. Wzajemna współpraca lokalnych społeczności może prowadzić do licznych korzyści w zakresie ochrony przyrody, ale także do wzrostu potencjału społecznego i ekonomicznego, o czym świadczą liczne przykłady podobnych miejsc w literaturze odnoszącej się do partycypacyjnego zarządzania środowiskiem (Stoll-Kleemann, Welp 2006; Beattie, Annis 2007). Wskazane jest zatem, aby wdrażać zdobytą pogłębioną wiedzę o obszarze Dolinek w praktykę zarządzania.

Podejście do zasadności stosowania podejścia partycypacyjnego w zarządzaniu przyrodą, choć powoli, zmienia się. W samej Polsce widać coraz więcej ich przykładów, np. badania terenowe „Obszary Natura 2000 a społeczność lokalna” połączone z edukacją ekologiczną skierowaną do szkół podstawowych oraz gimnazjalnych, znajdujących się w rejonach, w których występuje forma ochrony przyrody Natura 2000 (http://natura.ceo.org.pl/), efekt partycypacyjnego zarządzania obszarami Sieci Ekologicznej - powstanie w Adamkowie Ptasiej Wioski (http://www.adamkowo. tuchola.pl/). Istnieje wiele organizacji, które zajmują się prowadzeniem konsultacji społecznych oraz zachęcaniem do włączania się w zarządzanie, np. Dialog Społeczny Kraków (http://www.dialogspoleczny.krakow.pl).

Zarządzanie przyrodą w sposób partycypacyjny ma duży potencjał, jego rutynowe stosowanie wymaga jednak czasu, głównie ze względu na konieczność wypracowania społecznego zaufania, współpracy i odpowiedzialności. Wydaje się, iż Dolinki mają szansę stać się kolejnym dobrym przykładem uczestnictwa w podejmowaniu decyzji w polskiej ochronie przyrody. 


\section{Wnioski}

1. W badaniach nad zarządzaniem przyrodą zagadnienie jego społecznych aspektów pojawia się wciąż rzadziej aniżeli aspekty przyrodnicze. Ma to odbicie w przyjmowanych sposobach zarządzania w praktyce (Strzelecka i in. 2013). Europejska Sieć Ekologiczna Natura 2000 może pomóc w zmianie tej sytuacji ze względu na podkreślanie wagi społeczno-ekonomicznego pierwiastka przy jej implementacji.

2. Niniejsza praca stanowi zbiór ważnych wskazówek dla potencjalnych decydentów sektora ochrony przyrody - jak uwzględnienie potrzeb, preferencji i wartości różnych grup interesariuszy może pomóc w tworzeniu bardziej skutecznych Planów Zadań Ochronnych. Skuteczność i realność PZO, które mają uwzględniać ochronę w sposób systemowy i zintegrowany z potrzebami gospodarczymi danego regionu, zależy w głównej mierze od uczestnictwa w niej różnych grup interesariuszy, w tym lokalnej społeczności.

3. Niniejsze badanie $z$ użyciem technik jakościowych pomaga dotrzeć do takich indywidualnych opinii, wiedzy, preferencji planowania. Istnieje duża potrzeba tego typu badań, gdyż ochrona na terenach Natura 2000 stoi często w sprzeczności z potrzebą podejmowania tam działań gospodarczych, prowadząc ostatecznie do negatywnego nastawienia do tej formy ochrony przyrody, konfliktów i napięć (Dacko 2010; Kłodziński 2010). Aby móc efektywnie zarządzać środowiskiem, warto poznać przekonania i stanowiska poszczególnych interesariuszy, a dzięki temu starać się godzić sprzeczności interesów, minimalizować wzajemną niechęć oraz szukać najkorzystniejszych środowiskowo, społecznie i ekonomicznie kompromisów.

4. Partycypacja jest w Polsce pojęciem stosunkowo nowym, ale projekty takie jak „Wspólne zarządzanie przyrodą” mogą sprawić, że stanie się ono praktyką działania, która pomoże w rozwiązywaniu wielu problemów środowiskowych, nawet zanim one jeszcze powstaną.

\section{Bibliografia}

Alphandéry P., Fortier A. (2001). Can a territorial policy be based on science alone? The system for creating the Natura 2000 network in France. Sociologia ruralis, 41, 3, 311-328.

Arnstein S.R. (1969). A ladder of citizen participation. Journal of the American Institute of planners, 35, 4, 216-224.

Bal M., Bryde D., Fearon D., Ochieng E. (2013). Stakeholder engagement: Achieving sustainability in the construction sector. Sustainability, 5, 2, 695-710.

Beattie M., Annis R.C. (2007). Community Collaboration Project: Empowering Communities and Building Capacity 2005-2008 Integrated Performance Measurement \& Evaluation. Rural Development Institute, Brandon University. 
Brodie E., Cowling E., Nissen N., Paine A.E., Jochum V., Warburton D. (2009). Understanding Participation: A Literature Review. National Council for Voluntary Organisations.

Calvet-Mir L., Maestre-Andrés S., Molina J.L., van den Bergh J. (2015). Participation in protected areas: A social network case study in Catalonia, Spain. Ecology and Society, $20,4,45$.

Camp R.J., Knight R.L. (1998). Effects of rock climbing on cliff plant communities at Joshua Tree National Park, California. Conservation Biology, 12, 1302-1306.

Cent J., Grodzińska-Jurczak M., Pietrzyk-Kaszyńska A. (2014). The emerging multilevel environmental governance in Poland - local stakeholders involvement in the designation of Natura 2000 sites. Journal for Nature Conservation, 22, 93-102.

Cent J., Kobierska H., Grodzinska-Jurczak M., Bell S. (2007). Who is responsible for Natura 2000 in Poland? A potential role of NGOs in establishing the programme. International Journal of Environment and Sustainable Development, 6, 4, 422-435.

Czarnecki A. (2010). Sieć Natura 2000 w opinii lokalnych przedsiębiorców z terenu Zielonych Płuc Polski. Wieś i Rolnictwo, 1, 146, 187-201.

Dacko M. (2010). Sieć Natura 2000 a stan lokalnej gospodarki obszarów wiejskich Zielonych Płuc Polski - ujęcie modelowe. Wieś i Rolnictwo, 1, 146, 202-217.

Długosz D., Wygnański J.J. (2005). Obywatele współdecydują: przewodnik po partycypacji społecznej. Warszawa: Stowarzyszenie na rzecz Forum Inicjatyw Pozarządowych.

Dubel A. (2016). Dobre praktyki udziału społecznego w zarządzaniu środowiskiem na obszarach Natura 2000 [skrypt]. Karpacki Uniwersytet Partycypacji. Stowarzyszenie Ekopsychologia.

Dubel A. (red.), Cent J., Dubel K., Grodzińska-Jurczak M., Gutowska J., Kozieł M., Nieszporek K., Pietrzyk-Kaszyńska A. (2016). Wspólne zarządzanie przyrodą. Raport końcowy. Kraków: Stowarzyszenie Centrum Rozwiązań Systemowych.

Dubel A., Jamontt-Skotis M., Królikowska K., Czapski M., Dubel K. (2013). Metody rozwiązywania konfliktów na obszarach Natura 2000. Wrocław, Kraków: Stowarzyszenie Centrum Rozwiązań Systemowych.

Ducker D.J. (2012). A psychosocial approach to stakeholder participation in environmental problem solving. The case of the contaminated site cleanup at Mapua, New Zealand. Environmental Management and Sustainable Development, 1, 2, 163.

Elsawah S., Guillaume J.H., Filatova T., Rook J., Jakeman A.J. (2015). A methodology for eliciting, representing, and analysing stakeholder knowledge for decision making on complex socio-ecological systems: From cognitive maps to agentbased models. Journal of Environmental Management, 151, 500-516.

Gawin D., Gliński P. (red.) (2006). Civil Society in the Making. Warszawa: Wydawnictwo IFiS PAN.

Głogowska M., Szendera W., Chmielewski W. (2013). Konflikty społeczne na obszarach Natura 2000 w Polsce. Woda - Środowisko - Obszary Wiejskie, 13, 31-41.

Górska M. (2015). Europejska Sieć Ekologiczna Natura 2000. Warszawa: Ogólnopolskie Towarzystwo Ochrony Ptaków.

Grodzińska-Jurczak M. (2008). Rethinking of nature conservation policy in Poland: The need of human dimensions approach. Human Dimensions of Wildlife, 13, 380-381. 
Grodzińska-Jurczak M., Boćkowski M., Cent J., Pietrzyk-Kaszyńska A. (2012). Problemy społeczno-ekonomiczne przy wyznaczaniu obszarów Natura 2000 w Polsce. Socioeconomic problems during Natura 2000 site selection process. TEKA Komisji Ochrony i Kształtowania Środowiska Przyrodniczego Oddziału PAN w Lublinie, 9, 64-69.

Grodzińska-Jurczak M., Cent J. (2011a). Can public participation increase nature conservation effectiveness? Innovation. The European Journal of Social Science Research, 24, 3, 371-378.

Grodzińska-Jurczak M., Cent J. (2011b). Expansion of nature conservation areas: Problems with Natura 2000 implementation in Poland? Environmental Management, 47, 11-27.

Guzal-Dec D., Zwolińska-Ligaj M. (2010). Sieć Natura 2000 w świetle opinii wójtów i radnych reprezentujących gminy objęte europejską siecią ekologiczną. Wieś i Rolnictwo, $1,146,171-186$.

Habuda A. (2010). Pozycja prawna gminy wiejskiej w procedurze wyznaczania i ochrony obszarów Natura 2000. Wieś i Rolnictwo, 1, 146, 80-92.

Hirschnitz-Garbers M., Stoll-Kleemann S. (2011). Opportunities and barriers in the implementation of protected area management: A qualitative meta-analysis of case studies from European protected areas. The Geographical Journal, 177, 4, 321-334.

Hockings M., Stolton S., Leverington F., Dudley N., Courrau J. (2006). Evaluating Effectiveness: A Framework for Assessing Management Effectiveness of Protected Areas. Wyd. 2. Gland, Switzerland - Cambridge, UK: IUCN.

Houben G., Lenie K., Vanhoof K. (1999). A knowledge-based SWOT-analysis system as an instrument for strategic planning in small and medium sized enterprises. Decision support systems, 26, 2, 125-135.

Julien B., Lammertz M., Barbier J.M., Jen S., Ballesteros M., Bovis C.D., Krott M. (2000). Voicing interests and ConcErns: NATURA 2000: An ecological network in conflict with people. Forest Policy and Economics, 1, 3/4, 357-366.

Kamal S., Grodzińska-Jurczak M. (2014). Should conservation of biodiversity involve private land? A Q methodological study in Poland to assess stakeholders' attitude. Biodiversity and Conservation, 23, 11, 2689-2704.

Kłodziński M. (2010). Rozwój terenów wiejskich objętych siecią ekologiczną Natura 2000. Wieś i Rolnictwo, 1, 146, 146-156.

Krajick K. (1999). Scientists - and climbers - discover cliff eco systems. Science, 283, $1623-1624$.

Lemos M.C., Agrawal A. (2006). Environmental governance. Annual Review of Environment and Resources, 31, 297-325.

Lewenstein B., Schindler J., Skrzypiec R. (2010). Partycypacja społeczna i aktywizacja w rozwiązywaniu problemów społeczności lokalnych. Warszawa: Uniwersytet Warszawski, Stowarzyszenie CAL.

Obłój K. (2007). Strategia organizacji. Warszawa: Polskie Wydawnictwo Ekonomiczne.

Olech A. (red.) (2011). Partycypacja publiczna - o uczestnictwie obywateli $w$ życiu lokalnej wspólnoty politycznej. Warszawa: Instytut Spraw Publicznych.

Ostrom E. (2010). Beyond markets and states: polycentric governance of complex economic systems. Transnational Corporations Review, 2, 2, 1-12. 
Paloniemi R., Apostolopoulou E., Cent J., Bormpoudakis D., Scott A., Grodzińska-Jurczak M., Tzanopoulos J., Koivulehto M., Pietrzyk-Kaszyńska A., Pantis J. (2015). Public participation and environmental justice in biodiversity governance in Finland, Greece, Poland and the UK. Environmental Policy and Governance, 25, 5, 330-342.

Perepeczko B. (2010). Postawy i oczekiwania proekologiczne mieszkańców wsi obszarów chronionych. Wieś i Rolnictwo, 1, 146, 157-170.

Pietrzyk-Kaszyńska A., Grodzińska-Jurczak M. (2015). Bottom-up perspectives on nature conservation systems: The differences between regional and local administrations. Environmental Science \& Policy, 48, 20-31.

Poteete A.R., Janssen M.A., Ostrom E. (2010). Working Together: Collective Action, the Commons, and Multiple Methods in Practice. Princeton: Princeton University Press.

Rejt Ł. (2013). Przedmiot ochrony w OSO i SOO Natura 2000. Muzeum i Instytut Zoologii PAN, http://www.fwie.eco.pl/fwie/natura/przedmiot_ochrony.pdf [dostęp: 28.06.2017].

Scolozzi R., Schirpke U., Morri E., D’Amato D., Santolini R. (2014). Ecosystem services-based SWOT analysis of protected areas for conservation strategies. Journal of environmental management, 146, 543-551.

Silverman D. (2010). Prowadzenie badań jakościowych (tłum. J. Ostrowska, red. K.T. Konecki). Warszawa: Wydawnictwo Naukowe PWN.

Stoll-Kleemann S., Welp M. (red.) (2006). Stakeholders Dialogues in Natural Resources Management. Theory and Practice. Berlin-Heidelberg: Springer-Verlag.

Strzelecka M., Grodzinska-Jurczak M., Pietrzyk-Kaszynska A. (2013). Empowerment - istota czynnika ludzkiego w ochronie przyrody. Chrońmy Przyrodę Ojczysta, 69, 2, 86-95.

Yosie T.F., Herbst T.D. (1998). Using Stakeholder Processes in Environmental Decision making. An Evaluation of Lessons Learned, Key Issues, and Future Challenges. Ruder Finn, Washington: American Industrial Health Council.

Zawartka J. (2013). Park Krajobrazowy Dolinki Krakowskie przewodnik. Kraków: Zespół Parków Krajobrazowych Województwa Małopolskiego.

Żabiński L. (red.) (2000). Analiza strategiczna przedsiębiorstwa na potrzeby wyboru strategii rozwoju (za pomoca metody SWOT). Katowice: Wydawnictwo Akademii Ekonomicznej w Katowicach.

\section{Źródła internetowe}

SDF dla obszaru Dolinki Jurajskie, natura2000.gdos.gov.pl/datafiles/download/PLH120005/ sdf.

Strategia Rozwoju Gminy Krzeszowice (SRG Krzeszowice) na lata 2014-2022, http://bip. malopolska.pl/umkrzeszowice/Article/id,11921.html.

Strategia Rozwoju Gminy Wielka Wieś (SRG Wielka Wieś) na lata 2014-2020, http://bip. malopolska.pl/gwielkawies/Article/get/id,983967.html.

Strategia Rozwoju Gminy Zabierzów (SRG Zabierzów) na lata 2014-2020, http://zabierzow. org.pl/wp-content/uploads/2014/12/StrategiaRozwoju-Gminy-Zabierz\%C3\%B3w-nalata-2014-2020.pdf.

Strategia rozwoju społeczno-gospodarczego gminy Jerzmanowice-Przeginia (SRG Jerzmanowice-Przeginia) na lata 2014-2020, http://www.jerzmanowice-przeginia.pl/index. php/nowa-strategia-rozwoju-gminy. 
Ustawa z dnia października 2008 r. o udostępnianiu informacji o środowisku i jego ochronie, udziale społeczeństwa w ochronie środowiska oraz o ocenach oddziaływania na środowisko, http://isap.sejm.gov.pl/DetailsServlet?id=WDU20081991227.

Ustawa o Ochronie Przyrody z dnia 16 kwietnia 2004 r. Dz.U. 2004 nr 92, poz. 880, http:// isap.sejm.gov.pl/DetailsServlet?id=WDU20040920880.

\title{
Public Participation in Protected Area Management - A Case of Natura 2000 Site - Dolinki Jurajskie (Jurassic Valleys)
}

\begin{abstract}
A participatory model of protected area management, which is based on the cooperation of groups of various stakeholders and local communities, has so far been the most effective method of natural resources management. In Poland, it is relatively new and although well supported by legislation, it has not been widely applied in practice yet.

The aim of the article was to determine needs, preferences and conflicts, as well as participatory potential of various groups of stakeholders of Natura 2000 site - Dolinki Jurajskie PLH120005 (Jurassic Valleys) in developing a plan of protection tasks, and in managing this territory. The article provides for an analysis of a cooperation network between governing institutions, different perspectives of the stakeholders and their cooperation by applying qualitative methodology, namely SWOT analysis, SWOT connection analysis and in-depth interviews conducted in Dolinki Jurajskie (Jurassic Valleys) between May and July 2015. The results of this study include recommendations for institutions dealing with nature conservation in the area under investigation, as well as on other Natura 2000 sites in Poland.
\end{abstract}

Key words: public participation, Natura 2000, plan of protection tasks, managing environmental protection, social aspects of nature conservation. 